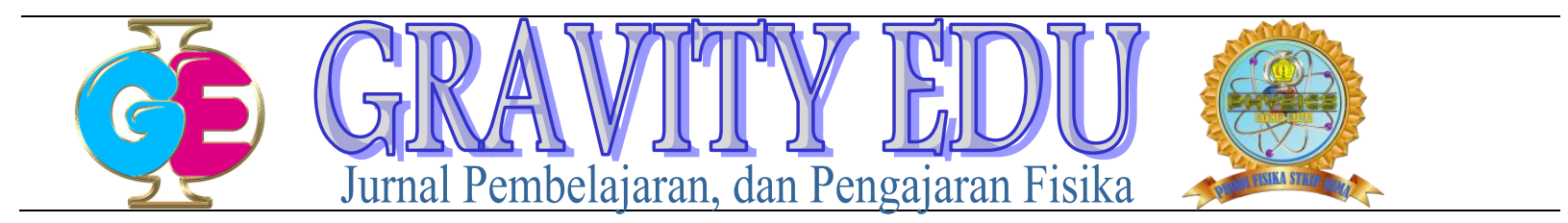

\title{
Pengaruh Media Scrapbook Terhadap Kemampuan Berpikir Kreatif Siswa
}

\author{
Arif Rahman Hakim ${ }^{1}{ }^{*}$, Hajarul Aswad ${ }^{2}$ ), Nurrahmah ${ }^{3}$ ) \\ 1,2) Prodi Pendidikan Guru Sekolah Dasar, STKIP Taman Siswa Bima \\ 3) Prodi Pendidikan Matematika, STKIP Taman Siswa Bima \\ Email : arifrahmanhakim50@gmail.com
}

\begin{abstract}
ABSTRAK : Penelitian ini bertujuan untuk mengetahui pengaruh media scrapbook terhadap kemampuan berpikir kreatif siswa. Jenis penelitian yang digunakan adalah Quasi Experiment dengan menggunakan desain penelitian Nonequivalent Control Group Design dengan sampel siswa kelas V SDN 59 Rasalewi Kota Bima.Instrumen yang digunakan dalam penelitian yaitu instrument tes dan lembar observasi. Analisis data yang digunakan berupa analisis persentase untuk kemampuan berpikir kreatif siswa, uji N-gain dan uji-t. Hasil analisis data menujukkan bahwa dari 21 orang jumlah siswa secara keseluruhan yaitu $76,19 \%$ atau 16 orang siswa mendapatkan N-gain dengan kategori tinggi dan $23,81 \%$ atau 5 orang siswa mendapatkan pengaruh kategori sedang. Hasil uji-t menunjukkan bahwa $t_{\text {hitung }}=2,259$ $>\mathrm{t}_{\text {tabel }}=1,725$ (taraf signifikan $\alpha=0,05$ ) sehingga Ha diterima dan $\mathrm{H}_{0}$ ditolak. Dengan demikian dapat disimpulkan bahwa terdapat pengaruh yang signifikan penggunaan media scrapbook terhadap kemampuan berpikir kreatif siswa.
\end{abstract}

\section{Kata kunci: Media Scrapbook, Kemampuan Berpikir Kreatif Siswa}

\begin{abstract}
This study aims to determine the effect of scrapbook media on students' creative thinking skills. The type of research used is Quasi Experiment using the Nonequivalent Control Group Design research design with a sample of fifth grade students at SDN 59 Rasalewi, Bima City. The instruments used in this research are test instruments and observation sheets. Analysis of the data used in the form of percentage analysis for students' creative thinking skills, N-gain test and t-test. The results of data analysis show that from 21 students the total number of students is $76.19 \%$ or 16 students get the $\mathrm{N}$-gain in the very high category and $23.81 \%$ or 5 students get the influence in the high category. The t-test results show that tcount $=2.259>$ ttable $=1.725$ (significant level $=0.05$ ) so Ha is accepted and $\mathrm{H} 0$ is rejected. Thus, it can be concluded that there is a significant effect of using scrapbook media on students' creative thinking abilities.
\end{abstract}

Keywords: Scrapbook Media, Students' Creative Thinking Ability

\section{PENDAHULUAN}

Tuntutan kemampuan berpikir kreatif dalam Kurikulum 2013 disebabkan karena kurikulum ini menekankan pada dimensi pedagogik modern yang harus diterapkan dalam pembelajaran, yaitu menggunakan pendekatan ilmiah yang meliputi mengamati, menanya, menalar, mencoba dan membentuk jejaring untuk semua mata pelajaran melalui penguatan sikap, keterampilan dan pengetahuan yang terintergrasi [1]. Pemikir kreatif mengevaluasi hasil dari proses berpikir seberapa baik keputusan atau seberapa baik masalah dapat diselesaikan. Kemampuan seperti inilah yang seharusnya ditanamkan pada siswa ketika masih mengenyam dunia pendidikan sebelum akhirnya terjun langsung di dunia masyarakat. Kemampuan siswa sebagai pembelajar mandiri dan mampu bekerja dalam kelompok serta menjadi komunikator yang baik, berani mengambil resiko dan juga mampu berpikir kritis diperlukan guna mempersiapkan diri di masa depan. Kemampuan berpikir kreatif merupakan suatu kompetensi yang harus dilatihkan pada peserta didik, karena kemampuan ini sangat diperlukan dalam kehidupan [2]. Hal ini bertolak belakang dengan kenyataannya di lapangan dimana masih banyak siswa yang mengalami kesulitan dalam menyelesaikan masalah ketika guru memberikan suatu permasalahan dalam pembelajaran. Selain itu, siswa juga harus diberi dorongan atau motivasi terlebih dahulu oleh gurunya baru berani menyampaikan pendapat dan berargumen dalam menyelesaikan masalah sehingga kemandirian siswa dalam menyelesaikan soal-soal masih kurang.

Hasil observasi awal yang telah dilakukan menunjukkan bahwa 1) Guru sudah menerapkan modelmodel kooperatif seperti mengelompokkan siswa dalam 
beberapa kelompok belajar, diskusi dan presentasi saat pembelajaran berlangsung. 2) Hasil belajar 47,62 \% (20 orang) siswa masih belum mencapai KKM yang telah ditentukan yakni 73,8. 3) Kemampuan berpikir kreatif siswa masih tergolong rendah, dibuktikan dengan rata-rata nilai IPA siswa sebesar 68,5 (kurang dari KKM), 4) Penggunaan media masih sangat minim. Dilihat dari cara pengajaran guru yang masih terbatas, sebagian guru hanya menggunakan buku guru dan buku siswa sebagai bahan ajar dan menempatkan guru sebagai sumber belajar tanpa adanya bantuan media, sehingga pembelajaran menjadi membosankan dan tidak menarik. Akibatnya siswa menjadi kurang termotivasi dalam pembelajaran. Selain itu proses pembelajaran yang dilakukan pada pembelajaran IPA masih cenderung bersifat parsial. Guru dalam menyampaikan materi pembelajaran di kelas masih kurang variatif. Proses pembelajaran memiliki kecenderungan pada metode tertentu, yaitu metode ceramah. Guru masih mendominasi dalam 3 proses pembelajaran. Dalam proses belajar siswa kurang aktif, siswa lebih banyak mendengar dan menulis. Hal tersebut menyebabkan siswa tidak memahami konsep yang sebenarnya, hanya menghafalkan suatu konsep sehingga menyebabkan materi yang sudah dipelajari siswa menjadi kurang bermakna. Selain itu, guru jarang menggunakan media pembelajaran karena kurang tersedianya media pembelajaran yang sesuai untuk materi pokok tertentu, dan penyampaian materi pembelajaran belum disampaikan secara sistematis. Oleh karena itu, perlu untuk dilakukan uji coba pembelajaran menggunakan media pembelajaran yang diharapkan dapat menarik perhatian siswa dalam menerima materi dan dapat berpengaruh pada peningkatan hasil belajar siswa untuk mencapai tujuan pembelajaran.

Bertolak dari permasalahan tersebut, maka perlu dilakukan inovasi dalam proses pembelajaran IPA untuk meningkatkan kemampuan belajar siswa salah satunya kemampuan berpikir keratif siswa. Pembelajaran dapat dikatakan efektif dan optimal apabila tujuan pembelajaran dapat tercapai. Tujuan pembelajaran akan tercapai apabila seorang pendidik dapat menciptakan situasi dan kondisi belajar yang baik dan secara efektif sehingga perencanaan, metode dan media pembelajaran yang digunakan oleh guru pun dapat memengaruhi potensi dan kemampuan yang dimiliki siswa, serta keberhasilan tersebut akan tercapai apabila siswa dilibatkan secara langsung dalam proses berpikirnya. Salah satu media pemeblajaran yang dapat digunakan untuk meningkatkan kemampuan berpikir kreatif siswa adalah media pembelajaran berupa media scrapbook.

Media pembelajaran berupa scrapbook merupakan salah satu media pembelajaran jenis 3 dimensi. Media ini berupa handmade yang dibuat dari kertas asturo maupun kertas karton. Scrapbook adalah album kenangan yang memuat bukan hanya photo, akan tetapi klipingan atau catatan penting yang berhubungan dengan sebuah moment. Bentuknya berbagai macam dekorasi, catatan atau bendabenda lainnya yang bisa di simpan didalamnya. Scrapbook juga dapat dikatakan sebagai seni menempel foto atau gambar dimedia kertas, dan menghiasnya menjadi karya kreatif [3]. Secara umum kelebihan dari media scrapbook antara lain adalah sebagai berikut: (1) Menarik: Media scrapbook memiliki tampilan yang menarik, dikarenakan scrapbook dibuat dari beraneka gambar yang dipadukan dan disusun sedemikian hingga denga memperhatikan keindahan. (2) Mudah dibuat: Scrapbook terbuat dari bahan-bahan yang ada dilingkungan sekitar, bahannya mudah diperoleh, cara pembuatannyapun tidak sulit sehingga mulai dari anak-anak sampai orang dewasa dapat membuat scrapbook. (3) Mudah dibawah dan disimpan: Pada umumnya scrapbook memiliki ukuran yang sama dengan buku, hal ini dapat memudahkan scrapbook untuk dibawa dan disimpan. Namun scrapbook sendiri mempunya bentuk yang bervariasi. (4) Bersifat realistis dalam menunjukkan pokok pembahasan: Dengan scrapbook dapat menunjukkan suatu obyek yang terlihat nyata melalui gambar dan foto. Dengan demikian kita akan lebih mudah untuk mengingatnya. (5) Dapat mengatasi keterbatasan waktu dan ruang: Dengan adanya scrapbook dapat menjadi salah satu solusi mengenai banyaknya peristiwa atau obyek yang sulit dikaitkan secara langsung [4]. Media pembelajaran berbasis buku tempel ini akan meningkatkan minat siswa yang melihatnya, karena media tersebut dikemas berupa buku gambar dimana gambar dan tulisannya timbul, sehingga seolah-olah buku tersebit seperti 3 dimensi. Penggunaan ilustrasi, warna, dan tipografi disesuaikan dengan kesukaan siswa sehingga siswa merasa lebih berimajinatif dalam membaca dan belajar. Hal demikian akan memberikan dampak yang bagus dalam peningkatan hasil belajar dan kemampuan berpikir kreatif siswa [5].

\section{METODE PENELITIAN}

Jenis penelitian yang digunakan adalah Quasi Experiment dengan menggunakan desain penelitian Nonequivalent Control Group Design. Kelas eksperimen dan kelas kontrol dipilih tanpa adanya penugasan random dan untuk setiap kelas diadakan pretest dan posttest [6]. Desain ini dapat digambarkan seperti pada Tabel 1.

Tabel 1. Desain Penelitian

\begin{tabular}{llll}
\hline Kelas & Pre-test & Treatment & Post-test \\
\hline Eksperimen & $\mathrm{X}_{1}$ & $\mathrm{O}$ & $\mathrm{Y}_{1}$ \\
\hline Kontrol & $\mathrm{X}_{2}$ & - & $\mathrm{Y}_{2}$ \\
\hline
\end{tabular}


Keterangan :
$\mathrm{X}_{1} \quad$ : Nilai pre-test kelas eksperimen
$\mathrm{X}_{2} \quad$ : Nilai pre-test kelas kontrol
$\mathrm{O} \quad$ : Menggunakan media scrapbook
: Pembelajaran biasa digunakan oleh guru
$\mathrm{Y}_{1} \quad$ : Nilai post-test kelas eksperimen
$\mathrm{Y}_{2} \quad$ : Nilai post-test kelas control

Adapun instrument yang digunakan dalam penelitian ini berupa instrument tes dan lembar observasi untuk memperoleh data sebagai berikut:

1. Hasil Belajar

Untuk mengetahui hasil belajar maka digunakan rumus berikut [7]:

$$
\%=\frac{\text { Jumlah skor yang diperoleh }}{\text { Jumlah skor total }} \times \text { Skor maksimum }
$$

\section{Kemampuan Berpikir Kreatif}

Data kemampuan berpikir kreatif siswa diukur dengan menggunakan lembar observasi dan dianalisis dengan menggunakan rumus berikut [8]:

$$
\%=\frac{\text { Jumlah skor yang diperoleh }}{\text { Jumlah skor total }} \times \text { Skor maksimum }
$$

Tabel 2. Kategori Kemampuan Berpeikir Kreatif (KBK)

\begin{tabular}{ll}
\hline Skor & Kategori \\
\hline $81 \leq \mathrm{KBK} \leq 100$ & Sangat Baik \\
\hline $61 \leq \mathrm{KBK} \leq 80$ & Baik \\
\hline $41 \leq \mathrm{KBK} \leq 60$ & Cukup \\
\hline $21 \leq \mathrm{KBK} \leq 40$ & Kurang \\
\hline $0 \leq \mathrm{KBK} \leq 20$ & Sangat Kurang \\
\hline
\end{tabular}

Sedangkan untuk mengetahui tingkatan pengaruh media scrapbook terhadap kemampuan berpikir kreatif siswa maka digunakan rumus rata-rata gain ternormalisasi [9]

$$
\mathrm{N} \text {-gain }=\frac{\text { Skor } \text { postest }- \text { skor } \text { pretest }}{\text { Skor ideal-Skor pretest }}
$$

Tabel 3. Kriteria Gain Ternormalisasi

\begin{tabular}{ll}
\hline Nilai N-gain & Kategori \\
\hline $0,70 \leq \mathrm{g} \leq 1,00$ & Tinggi \\
\hline $0,30 \leq \mathrm{g} \leq 0,70$ & Sedang \\
\hline $0,00 \leq \mathrm{g} \leq 0,30$ & Rendah \\
\hline $\mathrm{g}=0,00$ & Tidak terjadi peningkatan \\
\hline
\end{tabular}

Untuk mengetahui ada atau tidaknya pengaruh media scrapbook terhadap kemampuan berpikir kreatif siswa maka dilakukan pengujian hipotesis uji-t dengan menggunakan rumus berikut [10].

$$
\mathrm{t}=\frac{\bar{x}_{1}-\bar{x}_{2}}{\sqrt{\frac{s_{1}^{2}}{n_{1}}+\frac{s_{2}^{2}}{n_{2}}}}
$$

Keterangan :

$\bar{x}_{1}$ : Nilai rata-rata kelas eksperimen

$\bar{x}_{2}$ : Nilai rata-rata kelas kontrol

$s_{1}^{2}$ : Varians kelas eksperimen

$s_{2}^{2}$ : Varians kelas kontrol

$n_{1}$ : Jumlah siswa uji coba kelas eksperimen

$n_{2}$ : Jumlah siswa uji coba kelas kontrol

\section{HASIL DAN PEMBAHASAN}

Berdasarkan Munandar Berpikir Kreatif terdapat 5 Indikator antara lain: 1) Keterampilan Lancar, 2) keterampilan luwes, 3) keterampilan orisinal, 4) keterampilan merinci, 5) keterampilan mengevaluasi. Berdasarkan hasil observasi yang dilakukan selama penelitian dengan menggunakan instrument lembar observasi terkait kemampuan berpikir kreatif siswa SDN 59 Rasalewi Kota Bima menunjukan hasil seperti pada gambar berikut.

\section{Persetase Indikator Kemampuan Berpikir Kreatif Siswa}

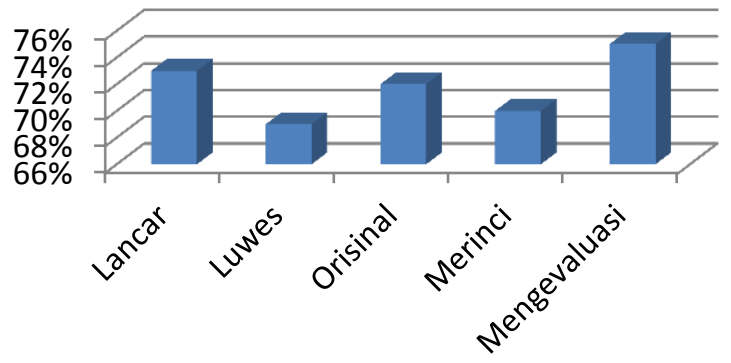

Gambar 1. Grafik persentase indikator kemampuan berpikir kreatif siswa

Gambar 1 menunjukkan bahwa rata-rata kemampuan berpikir kreatif siswa untuk semua indikator masuk kategori baik meskipun ada yang kurang dari $70 \%$ yakni pada indikator keluwesan.

Sedangkan untuk melihat tingkatan pengaruh media scrapbook terhadap kemampuan berpikir kreatif siswa dapat diperoleh dari perbedaan nilai pre-test dan post-test dengan rata-rata $\mathrm{N}$-gain sebagai berikut:

Tabel 4. Data hasil uji N-gain

\begin{tabular}{lllll}
\hline No & $\begin{array}{l}\text { Jumlah } \\
\text { Siswa }\end{array}$ & $\begin{array}{l}\text { Persentase } \\
(\%)\end{array}$ & Kriteria N-gain & Keterangan \\
\hline 1 & 16 & 76,19 & N-gain $>0,7$ & Tinggi \\
\hline 2 & 5 & 23,81 & $0,30 \leq \mathrm{g} \leq 0,70$ & Sedang \\
\hline
\end{tabular}

Dari tabel di atas terlihat bahwa dari 21 orang siswa secara keseluruhan diperoleh pengaruh media scrapbook sebanyak $76,19 \%$ atau 16 orang siswa pada kategori tinggi dan $23,81 \%$ atau 5 orang pada kategori sedang. Untuk mengetahui lebih jelas tingkat signifikansi pengaruh media scrapbook terhadap kemampuan berpikir kreatif siswa maka dapat dilihat dari hasil uji-tseperti yang ditunjukkan oleh tabel berikut: 
Tabel 5. Data hasil uji-t

\begin{tabular}{lll}
\hline Kelas & $\mathbf{t}_{\text {hitung }}$ & $\mathbf{t}_{\text {tabel }}$ \\
\hline Eksperimen & 2,259 & 1,725 \\
\hline
\end{tabular}

Dari hasil uji-t di atas menunjukkan bahwa $t_{\text {hitung }}=2,259>$ $\mathrm{t}_{\text {tabel }}=1,725$ (taraf signifikan $\alpha=0,05$ ) sehingga $\mathrm{Ha}$ diterima dan $\mathrm{H}_{0}$ ditolak. Dengan demikian dapat disimpulkan bahwa terdapat pengaruh yang signifikan penggunaan media scrapbook terhadap kemampuan berpikir kreatif siswa.

\section{KESIMPULAN}

Berdasarkan hasil di atas maka dapat disimpulkan bahwa terdapat pengaruh yang signifikan antara penggunaan media scrapbook terhadap kemampuan berpikir kreatif siswa kelas IV SDN 59 Rasalewi Kota Bima.

\section{UCAPAN TERIMAKASIH}

Terimakasih kepada kepala sekolah dan guru-guru di SDN 59 Rasalewi Kota Bima yang sudah memberikan kesempatan untuk melaksanakan penelitian ini sehingga menghasilkan karya tulis ini.

\section{DAFTAR PUSTAKA}

[1] Noer, S. H. 2009. Kemampuan Berpikir Kreatif Matematis Apa, Mengapa, dan Bagaimana? (pp. 521526). In Lampung: Prosiding Seminar Nasional Penelitian, Pendidikan dan Penerapan MIPA Fakultas MIPA, Universitas Negeri Yogyakarta (Vol. 16).

[2] Andiyana, M. A., Maya, R., \& Hidayat, W. 2018. Analisis Kemampuan Berpikir Kreatif Matematis Siswa SMP Pada Materi Bangun Ruang. JPMI (Jurnal Pembelajaran Matematika Inovatif), (Daring), Vol.1 (3): $239-248$.

[3] Damayanti, M. \& Ulhaq Z. (2017). Pengaruh Media Scrapbook (Buku Tempel) Terhadap Hasil Belajar Siswa Materi Keragaman Rumah Adat di Indonesia Kelas IV Sekolah Dasar. JPGSD. Vol. 5, No. 3, pp. 803-812.

[4] Sari, D. L. K \& Mintohari. (2018). Pengaruh Media Scrapbook Terhadap Hasil Belajar IPA Materi Sumber Energi Siswa Kelas IV SDN Lidah Kulon IV Surabaya. JPGSD. Vol. 6, No. 5, pp. 693-702.

[5] Syukur, M. 2011. Pengembangan Kemampuan Berpikir Kritis Siswa SMU Melalui Pembelajaran Matematika dengan Pendekatan Open-Ended. Tesis Tidak diterbitkan. Bandung: FPS, UPI Bandung.

[6] Sugiyono. (2016). Metode Penelitian Kuantitatif, Kualitatif, dan R\&D. Bandung: Alfabeta.
[7] Arikunto, S. (2010). Prosedur Penelitian/ Suatu Pendekatan Praktik. Jakarta : Rineka Cipta

[8] Rostina Sundayana, Statistika Penelitian Pendidikan, Bandung: Alfabeta, 2014, hal.151

[9] Budiyono. (2004). Statistika Untuk Penelitian. Surakarta: Sebelas Maret Universitiy Press

[10] Siregar, S. (2014). Statistik Parametik untuk Penelitian Kuantitatif: Dilengkapi dengan Perhitungan Manual dan Aplikasi SPSS Versi 17. Jakarta: Bumi Aksara. 